\title{
RESEARCH ON PHYSICO-CHEMICAL PRETREATMENT OF WASTEWATER FROM THE PRODUCTION OF WOOD COATING MATERIALS
}

\section{BADANIA NAD FIZYKOCHEMICZNYM PODCZYSZCZANIEM ŚCIEKÓW Z PRODUKCJI FARB DO DREWNA}

\begin{abstract}
This paper presents the results of the research conducted on the installation designed for physico-chemical pretreatment of technological wastewater in the volume of up to $5.0 \mathrm{~m}^{3} /$ day discharged from the production of protective and decorative coating materials used for wooden surfaces. The subject-matter installation constructed on a mobile pallet, consisted of a storage-averaging tank where concentrations were equalised with the use of circulation aeration and mixing. A variant, preliminary pre-oxidation with the use of hydrogen peroxide was conducted in this tank. A substantial installation set for the wastewater treatment plant consisted of two preliminary tube reactors, one cylindrical-conical processing reactor, stations for preparing and dispensing reagents and the sediment dewatering station. Considerable reductions in main chemical indicators of water pollution were obtained in the installation: both total suspended solids (TSS) and ether extract (EE) - more than $98 \%$, chemical oxygen demand (COD) - 46-54\%, biochemical oxygen demand (BOD 5$)-39-46 \%$, and free formaldehyde ( $\mathrm{HCHO}$ ) - 14-27\% due to the use of pre-oxidation and the acid - alkaine double coagulation by applying the ALCAT 105 - SAX 25 system. The use of pre-oxidation with hydrogen peroxide in doses $250.0-450.0 \mathrm{mg} / \mathrm{l}$ and then two-stage coagulation resulted in an increase in the reduction of: COD and BOD 5 by ca $10-15 \%$, and $\mathrm{HCHO}$ by $c a 58-66 \%$ with reference to the water pretreatment without pre-oxidation. The assessment of sediments formed during the process of pretreatment was made determining the leachable forms of metals $(\mathrm{Cu}, \mathrm{Ni}$ and Ti) according to methodology of TCLP in compliance with the US EPA Method 1311.
\end{abstract}

Keywords: wastewater from the production of wood coating materials, pre-oxidation, physico-chemical wastewater pretreatment

\footnotetext{
${ }^{1}$ Department of Chemical Technology and Engineering, University of Technology and Life Sciences, ul. Seminaryjna 3, 85-326 Bydgoszcz, Poland

${ }^{2}$ Department of Environmental Engineering, Vilnius Gediminas Technical University, Sauletekio al. 11, LT-10223 Vilnius-40, Lithuania

${ }^{3}$ Department of Research and Implementation, Projprzem-Eko Sp. z o.o., ul. Osiedlowa 1, 89-200 Zamość n. Bydgoszcz, Poland

*Corresponding author: zak@utp.edu.pl
} 


\section{Introduction}

The production of water dilutable protective and decorative paints for wooden surfaces generates the processing wastewater which often contains all components of parent paints but only in case of multiple dilution [1]. In the effluent, some indicating parameters are often significantly elevated due to the presence of higher volumes resulting from separate washing of containers for storing the components used during the production of coating materials [1-4]. The production of this type is usually a small-tonnage one and it significantly differs with reference to the assortment offered. Thus, the processing wastewater composition often varies considerably, also in terms of its quantities [1-3]. Typical components of the contamination load are the ingredients of parent paints, eg filling substances such as chalks (with major components: $\mathrm{CaCO}_{3}$ and $\mathrm{MgCO}_{3}$ ), barite (containing mainly $\mathrm{BaSO}_{4}$ ), talk (containing mainly magnesium hydroxysilicate $\mathrm{Mg}_{3}(\mathrm{OH})_{2} \mathrm{Si}_{4} \mathrm{O}_{10}$ ), kaolin (containing mainly kaolinite - alkaline aluminium silicate $\left(\mathrm{Al}_{4}\left[\mathrm{Si}_{4} \mathrm{O}_{10}\right](\mathrm{OH})_{8}\right)$ and fused quartz and mica), silica (mainly $\mathrm{SiO}_{2}$ ), mica (mainly alkaline aluminates such as: $\mathrm{AB}_{2-3}(\mathrm{OH}, \mathrm{F})_{2}\left(\mathrm{Si}_{1} \mathrm{Al}_{4} \mathrm{O}_{10}\right)$, where: $\mathrm{A}$ - mainly potassium, sodium and calcium, whereas $\mathrm{B}$ mainly iron, magnesium, manganese, lithium and aluminium), titanium white (containing mainly $\mathrm{TiO}_{2}$ ), siccatives, pigments, thickeners and surfactants, as well as defoaming agents [5-18]. Technological effluents generally contain significant concentrations of colloids and suspensions of a different degree of dispersion fastness, which is also a function of quantity and type of cross-linking agents added to semi-finished products, such as polyalcohols, polyurethanes, phenol-formaldehyde resins, urea-formaldehyde resins, amine-formaldehyde resins etc. [6-9]. Therefore, the elevated contents of free formaldehyde are frequently observed in raw effluents [1,2,19-21]. The pretreatment of wastewater in question is still practised by applying coagulating methods mainly, most often by one-stage coagulation with $\mathrm{pH}$ correction and final flocculation [1, 3, 22-28]. Coagulation methods belong to relatively effective ways of eliminating dispersed phases. However, they do not eliminate either dissolved loads or the general toxicity of pretreated wastewaters. Such a method of partial removal of dissolved pools loads is the two-stage coagulation connected with co-precipitation (CPT). In the literature, there are no experimental data on the effectiveness of this physico-chemical method of pretreating the wastewater from the production of coating materials for wooden surfaces and there are no data either on the effectiveness of using pre-oxidation at the initial stage of treating the effluents from such productions.

\section{Experimental part}

Considering a significant irregularity of the production and a wide range of variability in the produced assortment, the designed for physico-chemical pretreatment of processing effluents (Fig. 1) from the production plant of coating materials for protecting and painting wooden surfaces was constructed in such a way as to treat the effluents supplied in batches. This installation consists of: a mobile set for averaging the supplied and mixed raw wastewaters, including: a mobile tank for the processing effluents (1) (where raw wastewater was directly collected from the paint production lines), a compressor (1.1) used for pumping the air through a bubbler (1.2) for the aeration averaging of the effluents, and a wastewater circulation pump (1.3) used to improve the effect of averaging the effluents by pumping them cyclically through a tubular reactor (2). After their careful averaging and/or, optionally, after dosing $30 \%$ aqueous solution of hydrogen peroxide from the station (7) 
(before the tubular reactor (2) and in order to pre-oxide the impurities, crude wastewaters (CW) were supplied to the process tubular reactor (3) where the coagulant from station (8) was dosed. After this operation, a neutralising reagent was fed from station (9) or optionally, a second-stage coagulant acting also as a neutralising reagent was dosed. Then the pretreated wastewaters were directed to a central processing reactor (4) (vol. $1.0 \mathrm{~m}^{3}$ ) equipped with a slow-speed gate mixer (4.1).

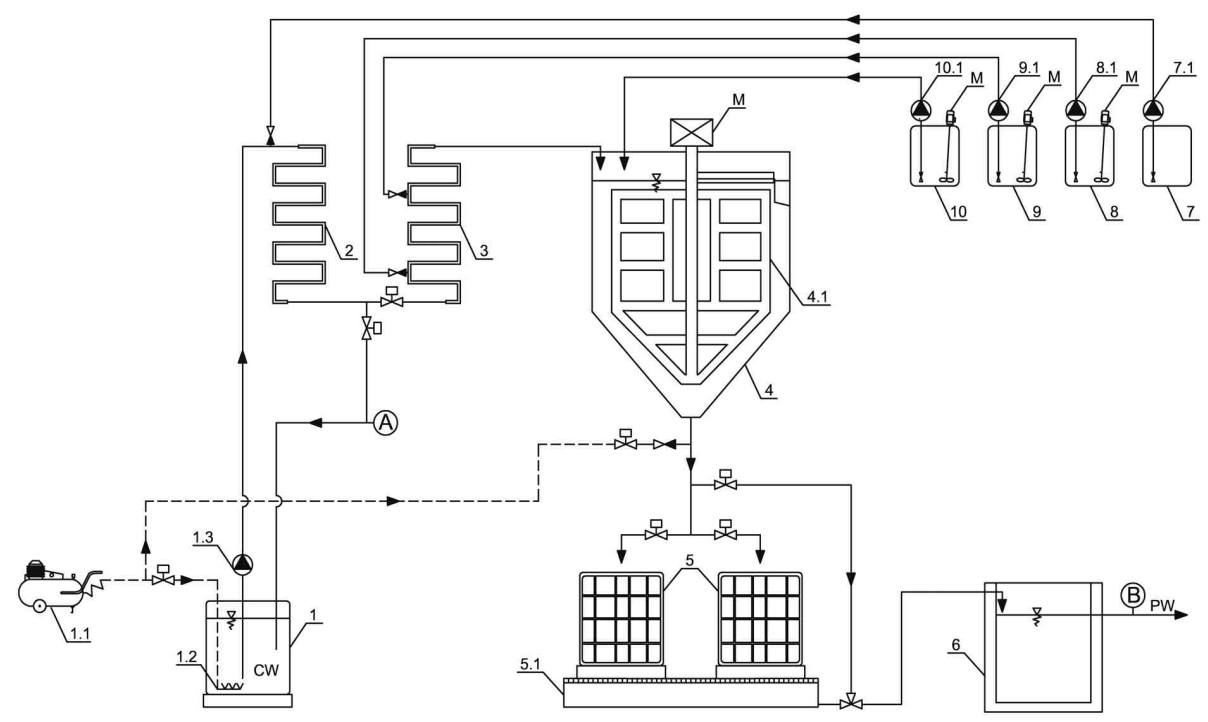

Fig. 1. Simplified flow diagram of the mobile experimental installation; where: 1 - mobile, aerated storage-averaging tank (optionally used for pre-oxidation), 1.1 - compressor, 1.2 - bubbler, 1.3 - wastewater circulation pump, 2 - tubular reactor to circulate raw effluents, 3 - process tubular reactor, 4 - central process reactor, 4.1 - gate mixer, 5 - sediment dewatering tank, 5.1 - tank for eluate, 6 - pretreated wastewater tank, 7 - perhydrol metering station, 8 - tank for coagulant (or first degree), 9 - reagent tank-neutralising antibody titre (or optionally for the 1st stage coagulant), 10 - station for preparing and dosing flocculant, M) mixer, 7.1-10.1 - reagent pumps, A and B - sampling points for specimens to be analysed

The averaging process was supported with a jet of air from the compressor (1.1), injected into the cone of the bottom part of the reactor (4). After an appropriate period of time, $0.3 \%$ flocculant solution was dosed from the station (10) directly to the reactor (4), (depending on the type of coagulation system, the flocculants of Floerger class (FLOPAM $^{\mathrm{TM}}$ FO 4800 SNF Floerger) or Kemipol were applied [29]). In the collected samples of averaged crude wastewaters (CW) (point A in Fig. 1) and at the outlet of the installation (point B in Fig. 1) in the pretreated wastewaters (PW), the following indicating parameters were determined in accordance with the applications given in the standards: reaction ( $\mathrm{pH})$ (PN-90/C-04540/01), total suspended solids (TSS) (PN-EN 872:2007), determination of chemical oxygen demand COD by dichromate method (PN-ISO 15705:2005), determination of biochemical oxygen demand $\mathrm{BOD}_{\mathrm{n}}$ by dilution method (PN-EN 1899-1:2002), determination of total nitrogen (TN) (PN-73/C-04576/12), 
ammonia nitrogen (AN) (PN-C-04576-4:1994), total phosphorus (TP) (PN-EN 1189-2000), ether extract (EE) (PN-EN 1899-1-2002) and formaldehyde (HCHO) (PN-71/C-04593). The heavy metals $(\mathrm{Cu}, \mathrm{Ni}$ and $\mathrm{Ti}$ ) contents analysis was made according to PN-EN ISO 118885:2009 on AAS 700 Perkin Elmer apparatus (in mineralizations $\mathrm{H}_{2} \mathrm{SO}_{4}$ $\left(\rho=1.8420 \mathrm{~g} / \mathrm{cm}^{3}\right)-\mathrm{HClO}_{4}\left(\rho=1.6510 \mathrm{~g} / \mathrm{cm}^{3}\right)$ in volumetric proportion 6:4). In cases when hydrogen peroxide was used, the values determining COD were corrected. The actual chemical oxygen demand was stated after correcting this value and subtracting a fraction formed by a residual hydrogen peroxide, on the basis of the relation: $C O D_{r}=C O D_{p}-f \cdot c$ $\left(C O D_{r}\right.$ - actual, $C O D_{p}$ - determined in the post-reaction sample, $c$ - concentration of $\mathrm{H}_{2} \mathrm{O}_{2}$ in the sample - determined by iodometric method, $f=0.25$ - correction factor and adopted on the basis of literature data [30-32]). The assessment of sediments formed during the process of pretreatment was made by determining the leachable forms of selected metals $(\mathrm{Cu}, \mathrm{Ni}$ and Ti) according to the methodology of TCLP (Toxicological Characteristic Leaching Procedure) in accordance with US EPA Method 1311 [33], using the apparatus: Perkin Elmer Optima Inductively Coupled Plasma-Atomic Emission Spectrometry (ICP-AES) for the final determinations.

\section{Results and discussion}

The construction of wastewater pretreatment plant was preceded by the research studies in a laboratory scale, the aim of which was to design the simplest and the most effective system of physico-chemical pretreatment for processing wastewater from the production of coating materials applied on wooden surfaces. The technological wastewater, which was mainly the water dilution of parent paints with the addition of detergents used in the final pressure and water cleaning of surfaces and production facilities, was characterised by a significant variability of its chemical composition and load and absolutely required to be pretreated. These effluents made mostly unstable suspensions and emulsions of the polydispersive system with a tendency to decay, which forced their pretreatment and keeping them in their raw state in the possibly shortest time. In spite of the fact that wastewaters contained raw components with biocidal activities, their detention resulted in an increase in soluble pools of $\mathrm{COD}, \mathrm{BOD}_{5}$, or $\mathrm{HCHO}$, at the same time, reducing the total level of eliminating these pollutants (Fig. 2).

The aim was to develop a simple method and installation to conduct the pretreatment of wastewaters from the production of paints to coat wooden surfaces, using the two-stage acidic-alkaline coagulation and/or the optional pre-oxidizing with hydrogen peroxide. Such an approach was associated with the results obtained in the laboratory, which unambiguously indicated that the effect of co-precipitation increases the reduction of COD, $\mathrm{BOD}_{5}$, total nitrogen (TN) and ammonia nitrogen (AN), and the use of hydrogen peroxide leads to an increase in the elimination of formaldehyde (HCHO) that is also present in the tested effluents. In practice, a combination of these two operations also resulted in a significant reduction in wastewater total toxicity due to a blockage or sorption of biocidal components, the function of which was fulfilled by $\mathrm{TiO}_{2}$ in case of the investigated wastewaters $[10,34]$. 

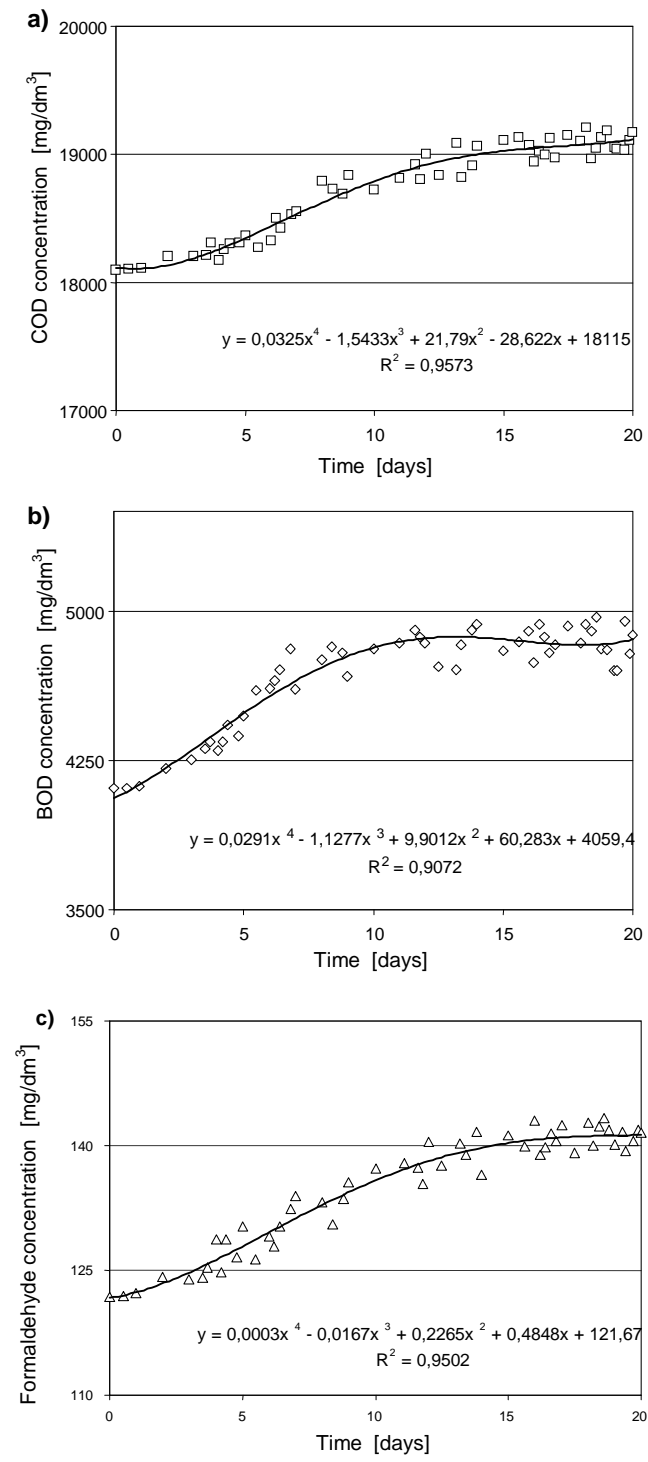

Fig. 2. The impact of retention time on instability in loads concentrations: a) COD, b) $\mathrm{BOD}_{5}$ and c) $\mathrm{HCHO}$ for an exemplary sample of raw wastewaters

The developed technical solution (presented as a simplified diagram in Figure 1) was tested in a plant producing a wide range of paints to coat wooden surfaces. The use of one-stage coagulation in the simplest variant with ferric coagulant PIX 113 and neutralization with water solution $(10 \%)$ of $\mathrm{NaOH}$ (to obtain $\mathrm{pH}=7.6-8.3$ ) reduced TSS by more than $98 \%$, EE by more than $96 \%$, while the reductions of COD loads ranged from $37-41 \%$, for $\mathrm{BOD}_{5}(34-39 \%)$, TN (21-31\%), AN (19-29\%), and $\mathrm{HCHO}(19-28 \%)$, 
occurring mainly in dispersed phase (Table 1). Such a solution is a simple way to eliminate only the pollutants dispersed in the aqueous phase, without any significant reduction in the pools of dissolved partial loads. The application of pre-oxidizing in doses $250.0-320.0 \mathrm{~g} / \mathrm{m}^{3}$ in this variant did not improve significantly the parameters of the pretreated wastewaters at the outlet from the installation. The tests carried out on activated sludge with the participation of pretreated by this method wastewaters showed evident disturbances in sludge operation (froth, sedimentation disorders, sedimentation, increased turbidity of sludge supernatant, sludge blackening, specific odour perceptible after ca 6-9 hours of intensive aeration and the contact of the pretreated effluent with sludge). The negative phenomena mentioned above occurred when the chambers were loaded with sludge at $1.25-3.44 \mathrm{~kg} \mathrm{~d}$.m. $/ \mathrm{m}^{3}$ in wastewater and with the load of pretreated effluents: COD ca 770-4100 $\mathrm{gO}_{2} / \mathrm{m}^{3}$. However, after three days of adaptation of the activated sludge in the treated wastewater environment (the aeration with air flow at 1.1-1.4 $\mathrm{m}^{3} / \mathrm{h}$ ), no signs of toxic action of the added pretreated wastewater against microbial communities were observed at the load of the activated sludge chambers at $1.65-3.91 \mathrm{~kg} \mathrm{~d} . \mathrm{m} . / \mathrm{m}^{3}$ and with the load of pretreated effluents COD ca 850-4400 $\mathrm{gO}_{2} / \mathrm{m}^{3}$.

Table 1

Values of analytical parameters for the crude wastewaters and pretreated effluents using PIX 113 - the aqueous solution of $\mathrm{NaOH}$

\begin{tabular}{|c|c|c|c|c|c|}
\hline Item & Parameter & Unit & $\begin{array}{c}\text { Crude processing } \\
\text { wastewater }\end{array}$ & $\begin{array}{c}\text { Pretreated } \\
\text { effluents }{ }^{a, b)}\end{array}$ & $\begin{array}{l}\text { Pretreated } \\
\text { effluents }\end{array}$ \\
\hline 1 & Reaction & {$[\mathrm{pH}]$} & $6.8-8.9$ & $7.2-8.1$ & $7.4-8.0$ \\
\hline 2 & Total suspended solids (TSS) & {$\left[\mathrm{mg} / \mathrm{dm}^{3}\right]$} & $1780.9-11708.3$ & $33.9-60.8$ & $48.4-88.9$ \\
\hline 3 & $\begin{array}{l}\text { Chemical oxygen demand } \\
\left(\mathrm{COD} \text { or } \operatorname{COD}_{\mathrm{r}}^{\mathrm{d})}\right)\end{array}$ & {$\left[\mathrm{mgO}_{2} / \mathrm{dm}^{3}\right]$} & $10550.6-25443.9$ & $6647.2-15063.0$ & $\begin{array}{l}6909.5- \\
17098.6^{\mathrm{d})}\end{array}$ \\
\hline 4 & $\begin{array}{l}\text { Biochemical oxygen demand } \\
\left(\mathrm{BOD}_{5}\right)\end{array}$ & {$\left[\mathrm{mgO}_{2} / \mathrm{dm}^{3}\right]$} & $1959.0-4052.7$ & $1294.5-2480.7$ & $1257.9-2708.6$ \\
\hline 5 & Total nitrogen $(\mathrm{TN})$ & {$\left[\mathrm{mgN} / \mathrm{dm}^{3}\right]$} & $219.8-450.8$ & $174.6-310.4$ & $172.3-317.4$ \\
\hline 6 & Ammonium nitrogen (AN) & {$\left[\mathrm{mgNH}_{4} / \mathrm{dm}^{3}\right]$} & $180.4-404.7$ & $145.4-285.7$ & $159.8-298.8$ \\
\hline 7 & Total phosphorus (TP) & {$\left[\mathrm{mgP} / \mathrm{dm}^{3}\right]$} & $22.8-41.6$ & $1.31-2.49$ & $0.93-3.14$ \\
\hline 8 & Ether extract (EE) & {$\left[\mathrm{mg} / \mathrm{dm}^{3}\right]$} & $23.9-87.3$ & $0.62-1.13$ & $0.67-1.46$ \\
\hline 9 & Formaldehyde (HCHO) & {$\left[\mathrm{mg} / \mathrm{dm}^{3}\right]$} & $51.9-111.8$ & $41.9-80.5$ & $48.9-88.5$ \\
\hline 10 & Copper $(\mathrm{Cu})$ & {$\left[\mathrm{mg} / \mathrm{dm}^{3}\right]$} & $2.22-5.25$ & $0.09-0.44$ & $0.17-0.45$ \\
\hline 11 & Nickel (Ni) & {$\left[\mathrm{mg} / \mathrm{dm}^{3}\right]$} & $1.84-3.76$ & $0.11-0.23$ & $0.26-0.43$ \\
\hline 12 & Titanium (Ti) & {$\left[\mathrm{mg} / \mathrm{dm}^{3}\right]$} & $2.91-13.23$ & $<0.05$ & $0.07-0.14$ \\
\hline
\end{tabular}

where: ${ }^{\text {a) }}$ dosage of PIX 113 was conducted to obtain $\mathrm{pH}=3.8-4.2$; ${ }^{\text {b) }}$ option without initial pre-oxidizing; ${ }^{\mathrm{c})}$ with the use of pre-oxidizing with $\mathrm{H}_{2} \mathrm{O}_{2}$ with a dose $250.0-320.0 \mathrm{~g} / \mathrm{m}^{3}$ of wastewater; ${ }^{d)} \mathrm{using} \mathrm{H}_{2} \mathrm{O}_{2}$, the values of COD were given as corrected ones: $C O D_{r}=C O D_{p}-f \cdot c(f=0.25$ based on the data from the study [30-32] $)$

The enhanced form of coagulation is the application of its two-stage option with the use of the second reagent functioning as a coagulant and a neutraliser (Tables 2 and 3). Such a solution causes the effect of co-precipitation manifesting an increase in the reduction of the dissolved pollutants load, which cannot be achieved during one-stage coagulation with neutralisation. Co-precipitation as a method of increasing the level of elimination, especially of soluble contaminant pools, is inseparably connected with the formation of solid $\mathrm{Fe}(\mathrm{OH})_{3(\mathrm{~s})}$ and $\mathrm{Al}(\mathrm{OH})_{3(\mathrm{~s})}$ and their reciprocal mixed forms arising from exceeding precipitability of thresholds for $\mathrm{Fe}^{3+} \cdot(\mathrm{aq})$ or $\mathrm{Al}^{3+} \cdot(\mathrm{aq})$ during neutralisation or during the second stage of coagulation combined with neutralisation [24, 35]. Then, while forming 
flocculant structures, a specific closing of soluble impurities (especially loads of COD, $\mathrm{BOD}_{5}$ and forms of nitrogen - to a lesser extent) takes place, which results in a measurable increase in the reduction of the contamination loads. During the two-stage coagulation, the induction of these phenomena is inextricably connected with the formation of increased quantities of sediments, which is not a desirable effect in the operational practice on the actual installation. By contrast, the pre-oxidation with hydrogen peroxide, the presence of which increases neither the quantity of burdensome post-processing sediments nor the secondary salinity of the pretreated wastewater flux, is also an effective way to increase the level of both $\mathrm{COD}$ and $\mathrm{BOD}_{5}$ reduction during wastewater treatment [36, 38]. Hydrogen peroxide is able to make selective and full oxidation and mineralisation of some organic compounds contained in the pool of pollutant load, which is applicable to decrease total chemical toxicity [34-38]. The use of hydrogen peroxide induces oxidation and combining the released particulates of organic and mineral matter in larger aggregations, which also affects the final effectiveness of eliminating colloid-suspension dispersions [36]. In this research, the oxidiser dose was selected in such a way as to obtain a maximum possible decrease in formaldehyde content with a maximum limit of trends to flotate the aggregated floccules of contaminants - a dose of 250-450 $\mathrm{gH}_{2} \mathrm{O}_{2} / \mathrm{m}^{3}$ of wastewater was determined. Pre-oxidation using hydrogen peroxide was carried out under conditions of the three-hour circulation by mixing it at ambient temperature. Such a solution enabled the partial oxidation of formaldehyde in accordance with simplified reactions a) and b) [36-38]: a) $\mathrm{HCHO}+\mathrm{H}_{2} \mathrm{O}_{2} \rightarrow \mathrm{HCOOH}+\mathrm{H}_{2} \mathrm{O}$, b) $\mathrm{HCOOH}+\mathrm{H}_{2} \mathrm{O}_{2} \rightarrow \mathrm{CO}_{2}+2 \mathrm{H}_{2} \mathrm{O}$. Clearly, the lower level of reduction in formaldehyde concentration by oxidation with hydrogen peroxide was found after the application of PIX 113 at the first stage of coagulation. This phenomenon may be mainly interpreted by catalysing activity of $\mathrm{Fe}$ (III) ions, resulting in decomposition of hydrogen peroxide in accordance with a series of radical, ionic and radical-ionic reactions found in literature, ie [24, 36-42]: $\mathrm{Fe}^{3+} \cdot \mathrm{aq}+\mathrm{H}_{2} \mathrm{O}_{2} \rightarrow \mathrm{Fe}^{2+} \cdot \mathrm{aq}+$ $\mathrm{HO}_{2}{ }^{\cdot}+\mathrm{H}^{+}, \mathrm{Fe}^{3+} \cdot \mathrm{aq}+\mathrm{HO}_{2}{ }^{\cdot} \rightarrow \mathrm{Fe}^{2+} \cdot \mathrm{aq}+\mathrm{O}_{2}+\mathrm{H}^{+}, \mathrm{Fe}^{3+} \cdot \mathrm{aq}+\mathrm{HO}^{\cdot} \rightarrow \mathrm{FeOH}^{3+} \rightarrow \mathrm{FeO}^{2+}$. $\mathrm{aq}+\mathrm{H}^{+}, 2 \mathrm{Fe}^{3+} \cdot \mathrm{aq}+\mathrm{H}_{2} \mathrm{O}_{2} \rightarrow 2 \mathrm{Fe}^{2+} \cdot \mathrm{aq}+\mathrm{O}_{2}+2 \mathrm{H}^{+}$etc. During these transformations, a significant participation can be certainly attributed to the reactions described by literature as Fenton's system, or the Haber-Weiss or Haber-Willstätter systems, and the whole series of reactions initiated by the presence of iron $\mathrm{Fe}(\mathrm{II})$, ie [39, 42, 43]: $\mathrm{Fe}^{2+} \cdot \mathrm{aq}+\mathrm{H}_{2} \mathrm{O}_{2} \rightarrow$ $\mathrm{Fe}^{3+} \cdot \mathrm{aq}+\mathrm{HO}^{\cdot}+\mathrm{OH}^{-}, \mathrm{Fe}^{2+} \cdot \mathrm{aq}+\mathrm{H}_{2} \mathrm{O}_{2} \rightarrow \mathrm{FeO}^{2+} \cdot \mathrm{aq}+\mathrm{H}_{2} \mathrm{O}, \mathrm{FeO}^{2+} \cdot \mathrm{aq}+\mathrm{H}_{2} \mathrm{O}_{2} \rightarrow$ $\mathrm{Fe}^{2+} \cdot \mathrm{aq}+\mathrm{O}_{2}$, as well as the reaction of $\mathrm{Fe}(\mathrm{II})$ with radical products, $e g: \mathrm{Fe}^{2+} \cdot \mathrm{aq}+\mathrm{HO}^{\cdot} \rightarrow$ $\mathrm{Fe}^{3+} \cdot \mathrm{aq}+\mathrm{OH}^{-}, \mathrm{Fe}^{2+} \cdot \mathrm{aq}+\mathrm{HO}_{2}{ }^{-} \rightarrow \mathrm{Fe}^{3+} \cdot \mathrm{aq}+\mathrm{HO}_{2}^{-}$etc. The result of a very probable parallel course of these reactions to the coagulation was an intense foaming at the initial stage, just after dosing perhydrol, which worsened the quality of the wastewater at their outlet (Tables 1 and 2). Definitely, the most effective one occurred to be a variant of pre-oxidizing and two-stage coagulation based on aluminium coagulants (Table 3 ). The use of pre-oxidation with hydrogen peroxide in doses $250.0-450.0 \mathrm{mg} / \mathrm{dm}^{3}$ and then two-stage coagulation resulted in an increase in the reduction of: $\mathrm{COD}$ and $\mathrm{BOD}_{5}$ by $c a 10-15 \%$, and $\mathrm{HCHO}$ by $\mathrm{ca} 58-66 \%$ with reference to the water pretreatment without pre-oxidation. In this variant, a total reduction of the individual loads was at the level of: TSS, EE and TP (more than 99\%), COD (51-61\%), BOD 5 (45-54\%), TN (43-56\%), AN (46-56\%), HCHO (66-75\%), heavy metals $\mathrm{Cu}$ and $\mathrm{Ni}$ (below $0.2 \mathrm{mg} / \mathrm{dm}^{3}$ ), and $\mathrm{Ti}$ (below $0.05 \mathrm{mg} / \mathrm{dm}^{3}$ ). However, volumetric quantities of generated deposits were relatively the highest and showed a very fragmented structure, which required increased doses of flocculant. The 
efficiency of ALCAT 105 - SAX 25 system results from a relatively highest consumption of hydrogen peroxide for the oxidation processes of organic pollutants, partially including the elimination of formaldehyde. Basic components of chloride coagulants, polyaluminium chloride (ALCAT 105) and sodium aluminate (SAX 25) in the environment of the tested wastewater are chemically inert against hydrogen peroxide, not causing its degradation or blocking (of eg coordination type). The wastewater pretreated by this method showed no toxicity with reference to activated sludge during the tests for their biological treatment with the load of sludge in the chamber at $1.75-5.52 \mathrm{~kg} \mathrm{~d} . \mathrm{m} . / \mathrm{m}^{3}$ of wastewater and the COD load of pretreated sewage $\mathrm{ca} 1250-5200 \mathrm{gO}_{2} / \mathrm{m}^{3}$. Additional tests with the use of zeolite Zeochem ${ }^{\circledR}$, grain size $0.01-0.1 \mathrm{~mm}$ in doses $0.35-1.25 \mathrm{~kg} / \mathrm{m}^{3}$ of treated wastewater did not raise any measurable reduction of any of the analysed pollutants in case of any tested variant. However, it increased the sedimentation rate (by ca 20-25\%) of particles thickened by flocculation. A small, measurable increase in the reduction level was observed only in case of nitrogen (TN) by ca $8-13 \%$ and ammonia nitrogen (AN) by $c a 9-16 \%$ with zeolite doses of $0.75 \mathrm{~kg} / \mathrm{m}^{3}$ of the treated wastewater. The further increase in dosed zeolite resulted only in a higher reduction of total nitrogen (TN) by $15-33 \mathrm{mgN} / \mathrm{kg}$ and ammonia nitrogen by $16-37 \mathrm{mgNH}_{4} / \mathrm{kg}$ of zeolite.

Values of analytical parameters for the tested crude wastewaters and pretreated effluents

Table 2 with the use PIX 113 - SAX 25 system

\begin{tabular}{|c|c|c|c|c|c|}
\hline Item & Parameter & Unit & $\begin{array}{c}\text { Crude processing } \\
\text { waste water }\end{array}$ & $\begin{array}{l}\text { Pretreated } \\
\text { effluents }{ }^{\text {a, b) }}\end{array}$ & $\begin{array}{l}\text { Pretreated } \\
\text { effluents c) }\end{array}$ \\
\hline 1 & Reaction & {$[\mathrm{pH}]$} & $6.5-8.3$ & 7.6-8.0 & 7.4-8.3 \\
\hline 2 & Total suspended solids (TSS) & {$\left[\mathrm{mg} / \mathrm{dm}^{3}\right]$} & $1440.9-6405.4$ & $33.2-38.9$ & $15.0-24.9$ \\
\hline 3 & $\begin{array}{l}\text { Chemical oxygen demand } \\
\left(\mathrm{COD} \text { or } \mathrm{COD}_{\mathrm{r}}^{\mathrm{d})}\right)\end{array}$ & {$\left[\mathrm{mgO}_{2} / \mathrm{dm}^{3}\right]$} & $11302.6-27440.8$ & $6309.7-13033.4$ & $\left.7111.9-13888.7^{d}\right)$ \\
\hline 4 & $\begin{array}{l}\text { Biochemical oxygen demand } \\
\left(\mathrm{BOD}_{5}\right)\end{array}$ & {$\left[\mathrm{mgO}_{2} / \mathrm{dm}^{3}\right]$} & $1759.0-5052.7$ & 937.9-2988.7 & $1077.0-2789.0$ \\
\hline 5 & Total nitrogen $(\mathrm{TN})$ & {$\left[\mathrm{mgN} / \mathrm{dm}^{3}\right]$} & $131.0-297.1$ & 90.6-193.3 & $85.3-185.6$ \\
\hline 6 & Ammonium nitrogen (AN) & $\begin{array}{c}{\left[\mathrm{mgNH}_{4} /\right.} \\
\left.\mathrm{dm}^{3}\right]\end{array}$ & $97.5-240.3$ & $60.7-146.2$ & $57.9-148.1$ \\
\hline 7 & Total phosphorus (TP) & {$\left[\mathrm{mgP} / \mathrm{dm}^{3}\right]$} & $26.9-55.9$ & $0.6-1.4$ & $0.5-1.2$ \\
\hline 8 & Ether extract (EE) & {$\left[\mathrm{mg} / \mathrm{dm}^{3}\right]$} & $37.2-100.4$ & $0.6-1.5$ & $0.3-1.1$ \\
\hline 9 & Formaldehyde (HCHO) & {$\left[\mathrm{mg} / \mathrm{dm}^{3}\right]$} & $43.5-107.1$ & $28.5-82.9$ & $21.9-67.4$ \\
\hline 10 & Copper $(\mathrm{Cu})$ & {$\left[\mathrm{mg} / \mathrm{dm}^{3}\right]$} & $2.94-7.38$ & $1.08-1.36$ & $0.04-0.25$ \\
\hline 11 & Nickel (Ni) & {$\left[\mathrm{mg} / \mathrm{dm}^{3}\right]$} & $2.76-5.28$ & $0.24-0.57$ & $0.12-0.23$ \\
\hline 12 & Titanium (Ti) & {$\left[\mathrm{mg} / \mathrm{dm}^{3}\right]$} & $1.77-7.73$ & $<0.05$ & $<0.05$ \\
\hline
\end{tabular}

where: ${ }^{\text {a) }}$ dosage of PIX 113 was conducted to obtain $\mathrm{pH}=3.9-4.3 ;{ }^{\text {b) }}$ option without initial pre-oxidizing; ${ }^{\mathrm{c})}$ with the use of pre-oxidizing with $\mathrm{H}_{2} \mathrm{O}_{2}$ with a dose $250.0-320.0 \mathrm{~g} / \mathrm{m}^{3}$ of wastewater; ${ }^{\mathrm{d})} \mathrm{using} \mathrm{H}_{2} \mathrm{O}_{2}$, the values of COD were given as corrected ones: $C O D_{r}=C O D_{p}-f \cdot c(f=0.25$ based on the data from the study [30-32] $)$

Dehydrated post-processing sediments were subject to the TCLP procedure after wastewater treatment in order to determine the concentrations of such metals as $\mathrm{Cu}, \mathrm{Ni}$ and Ti. The value of $\mathrm{Ti}$ in all analysed samples was below the determination limit of the method, similarly to Ni in sediments obtained with the use of ALCAT 105 - SAX 25 system. The nickel content in post-processing sediments from all the tested variants did not exceed the suggested standard limit value of $15 \mathrm{mg} / \mathrm{dm}^{3}$, thus the obtained deposits can be considered as safe [33]. Copper and titanium are not regulated in the assessment TCLP criteria. 
Analysing the obtained values of TCLP test, it can be stated that they are additional confirmation of the most advantageous processing system under the option $\mathrm{C}$.

Table 3

Values of analytical parameters for the tested crude wastewaters and pretreated effluents with the use of ALCAT 105 - SAX 25 system

\begin{tabular}{|c|c|c|c|c|c|}
\hline Item & Parameter & Unit & $\begin{array}{c}\text { Crude processing } \\
\text { waste water }\end{array}$ & $\begin{array}{c}\text { Pretreated } \\
\text { effluents } \mathbf{a}, \mathbf{b})\end{array}$ & $\begin{array}{c}\text { Pretreated } \\
\text { effluents }\end{array}$ \\
\hline 1 & Reaction & {$[\mathrm{pH}]$} & $6.7-8.6$ & $7.2-7.7$ & $7.4-8.2$ \\
\hline 2 & Total suspended solids (TSS) & {$\left[\mathrm{mg} / \mathrm{dm}^{3}\right]$} & $1220.7-4304.2$ & $11.5-24.3$ & $10.1-20.6$ \\
\hline 3 & $\begin{array}{c}\text { Chemical oxygen demand } \\
\left(\text { COD or COD }{ }_{\mathrm{r}}{ }^{\mathrm{d})}\right)\end{array}$ & {$\left[\mathrm{mgO}_{2} / \mathrm{dm}^{3}\right]$} & $13036.7-26008.8$ & $7039.8-11964.1$ & $\begin{array}{c}6349.7- \\
10164.3^{\mathrm{d})}\end{array}$ \\
\hline 4 & $\begin{array}{c}\text { Biochemical oxygen demand } \\
\text { (BOD })\end{array}$ & {$\left[\mathrm{mgO}_{2} / \mathrm{dm}^{3}\right]$} & $2504.5-5879.7$ & $1528.2-3176.1$ & $1379.6-2694.7$ \\
\hline 5 & Total nitrogen (TN) & {$\left[{\left.\mathrm{mgN} / \mathrm{dm}^{3}\right]}^{3}\right.$} & $340.8-480.3$ & $207.9-266.3$ & $159.2-203.3$ \\
\hline 6 & Ammonium nitrogen $(\mathrm{AN})$ & {$\left[\mathrm{mgNH} / \mathrm{dm}^{3}\right]$} & $280.5-430.6$ & $195.0-240.3$ & $154.9-189.4$ \\
\hline 7 & Total phosphorus (TP) & {$\left[\mathrm{mgP} / \mathrm{dm}^{3}\right]$} & $31.3-64.0$ & $0.7-1.2$ & $0.4-0.8$ \\
\hline 8 & Ether extract (EE) & {$\left[\mathrm{mg} / \mathrm{dm}^{3}\right]$} & $29.6-89.4$ & $0.5-0.9$ & $0.2-0.4$ \\
\hline 9 & Formaldehyde (HCHO) & {$\left[\mathrm{mg} / \mathrm{dm}^{3}\right]$} & $79.7-138.0$ & $68.4-100.7$ & $28.5-33.6$ \\
\hline 10 & Copper $(\mathrm{Cu})$ & {$\left[\mathrm{mg} / \mathrm{dm}^{3}\right]$} & $2.36-6.60$ & $0.74-1.13$ & $0.02-0.12$ \\
\hline 11 & Nickel $(\mathrm{Ni})$ & {$\left[\mathrm{mg} / \mathrm{dm}^{3}\right]$} & $2.75-4.85$ & $0.20-0.52$ & $0.08-0.20$ \\
\hline 12 & Titanium (Ti) & {$\left[\mathrm{mg} / \mathrm{dm}^{3}\right]$} & $2.93-10.68$ & $<0.05$ & $<0.05$ \\
\hline
\end{tabular}

where: ${ }^{\text {a) }}$ dosage of ALCAT 105 was conducted to obtain $\mathrm{pH}=4.1-4.4$; ${ }^{\text {b) }}$ option without initial pre-oxidizing; ${ }^{c)}$ with the use of pre-oxidizing with $\mathrm{H}_{2} \mathrm{O}_{2}$ with a dose $250.0-320.0 \mathrm{~g} / \mathrm{m}^{3}$ of wastewater; ${ }^{\mathrm{d})}$ using $\mathrm{H}_{2} \mathrm{O}_{2}$, the values of COD were given as corrected ones: $C O D_{r}=C O D_{p}-f \cdot c(f=0.25$ based on the data from the study [30-32]

Table 4

Concentrations of selected heavy metals determined in compliance with the TCLP procedure for post-processing sediments

\begin{tabular}{|c|c|c|c|}
\hline Analyte $^{\text {a) }}$ & A & B & C \\
\hline $\mathrm{Cu}$ & $0.114-0.227$ & $0.071-0.193$ & $0.012-0.049$ \\
\hline $\mathrm{Ni}$ & $0.212-0.413$ & $0.084-0.168$ & $<0.05$ \\
\hline $\mathrm{Ti}$ & $<0.005$ & $<0.005$ & $<0.005$ \\
\hline
\end{tabular}

where clause: the coagulation systems, respectively: A) PIX 113 - NaOH, B) PIX 113 - SAX 25, C) ALCAT 105 $\mathrm{SAX} 25 ;{ }^{\mathrm{a})}$ metal concentrations are given in $\left[\mathrm{mg} / \mathrm{dm}^{3}\right]$

\section{Conclusions}

The production of decorative and protective materials for coating wooden surfaces is connected with forming the processing wastewater characterised by a significant variation in the chemical composition and pollution loads. The use of the two-stage coagulation enables a deeper reduction in loads of $\mathrm{COD}$ and $\mathrm{BOD}_{5}$, including the soluble parts of these loads. However, it is associated with generating larger quantities of the post-processing sediments. Pre-oxidation with the use of hydrogen peroxide results in significantly higher formaldehyde $(\mathrm{HCHO})$ reduction and in an increase in the reduction of both COD and $\mathrm{BOD}_{5}$ loads level in case of two-stage acidic-alkaline coagulation using aluminium reagents (of type ALCAT 105 - SAX 25). 


\section{References}

[1] Jewell LL, Fasemore OA, Glasser D, Hildebrandt D, Heron L, Van Wyk N, et al. Toward zero waste production in the paint industry. Water SA. 2004;30(5):643-647.

[2] Kaczala F, Marques M, Hogland W. Biotreatability of wastewater generated during machinery washing in a wood-based industry: COD, formaldehyde and nitrogen removal. Bioresour Technol. 2010;101(23):8975-8983. DOI: 10.1016/j.biortech.2010.06.122.

[3] Huang CP, Ghadirian M. Physical chemical treatment of paint industry wastewater. J Water Pollut Contr Fed. 1974;46(10):2340-2346.

[4] Kutluay G, Babuna FG, Eremektar G, Orhon D. Treatability of water-based paint industry effluents. Fresenius Environ Bull. 2004;13(10):1057-1060.

[5] Oldring PKT. Coatings, Colorants, and Paints. In: Encyclopedia of Physical Science and Technology (Third Edition), Wimbledon, England UK: Academic Press; 2003; 175-190. DOI: 10.1016/B0-12-2274105/00115-0.

[6] Höfer R. 10.22. Processing and Performance Additives for Coatings. Polymer Science - A Comprehensive Reference, Volume 10: Polymers Sust Environ Green Energy. 2012; 383-396. DOI: 10.1016/B978-0-44453349-4.00273-9.

[7] Bulian F, Graystone JA. Chapter 3. Raw Materials for Wood Coatings (1) - Film Formers (Binders, Resins and Polymers), 53-94 and Chapter 5. Classification and Formulation of Wood Coatings, 137-154. In: Wood Coatings. Theory and practice. Elsevier; 2009; DOI: 10.1016/B978-0-444-52840-7.00005-9.

[8] Imam SH, Gordon SH, Mao L, Chen L. Environmentally friendly wood adhesive from a renewable plant polymer: characteristics and optimization. Polymer Degrad Stabil. 200;73(3):529-533. DOI: 10.1016/S0141-3910(01)00114-8.

[9] Landry V, Blanchet P, Weathering resistance of opaque PVDF-acrylic coatings applied on wood substrates. Progr Org Coating. 2012;75(4):494-501. DOI: 10.1016/j.porgcoat.2012.06.004.

[10] Liauw C, Allen NS, Edge M, Ortega A, Stratton J, McIntyre RB. Behaviour of nanoparticle (ultrafine) titanium dioxide pigments and stabilisers on the photooxidative stability of water based acrylic and isocyanate based acrylic coatings. Polymer Degrad Stabil. 2002;78(3):467-478. DOI: 10.1016/S0141-3910(02)00189-1.

[11] Donkers PAJ, Huinink HP, Erich SJF, Reuvers NJW, Adan OCG. Water permeability of pigmented waterborne coatings. Progr Org Coating. 2013;76(1):60-69. DOI: 10.1016/j.porgcoat.2012.08.011.

[12] Prasad MS, Reid KJ, Murray KK. Kaolin: processing, properties and applications. Appl Clay Sci. 1991;6(2):87-119. DOI: 10.1016/0169-1317(91)90001-P.

[13] Dhyani S, Kamdem DP. Bioavailability and form of copper in wood treated with copper-based preservative. Wood Sci Tech. 2012;46(6):1203-1213. DOI: 10.1007/s00226-012-0475-x.

[14] Grāvitis J, Ābolinš J, Tupčiauskas R, Vēveris A. Lignin from steam-exploded wood as binder in wood composites. J Environ Eng Landsc Manage. 2010;18(2):75-84. DOI: 10.3846/jeelm.2010.09.

[15] Bellotti N, Deyá C, del Amo B, Romagnoli R. "Quebracho" tannin derivative and boosters biocides for new antifouling formulations. J Coating Tech Res. 2012;9(5):551-559. DOI: 10.1007/s11998-012-9403-0.

[16] Grynkiewicz-Bylina B. Testing of toxic elements migration from the materials used as toy coatings. Ecol Chem Eng S. 2011;18(2):223-231.

[17] Hellgren A-C, Weissenborn P, Holmberg K. Surfactants in water-borne paints. Progr Org Coating. 1999;35(1-4):79-87. DOI: 10.1016/S0300-9440(99)00013-2.

[18] Holmberg K. Unsaturated monoethanolamide ethoxylates as paint surfactants. Progr Colloid Polymer Sci. 1996;101:69-74. DOI: 10.1007/BFb0114446.

[19] Garrido JM, Méndez R. Treatment of wastewaters from a formaldehyde-urea adhesives factory. Water Sci Tech. 2000;42(5-6):293-300.

[20] Eiroa M, Vilar A, Kennes C, Veiga MC. Biological treatment of industrial wastewater containing formaldehyde and formic acid. Water SA. 2006;32(1):115-118.

[21] Campos JL, Sanchez M, Corral-Mosquera A, Mendez R, Lema JM. Coupled BAS and anoxic USB system to remove urea and formaldehyde from wastewater. Water Res. 2003;37(14):3445-3451. DOI: 10.1016/S0043-1354(03)00011-3.

[22] Dovletoglou O, Philippopoulos C, Grigoropoulou H. Coagulation for treatment of paint industry wastewater. J Environ Sci Health Part A. 2002;37(7):1361-1377. DOI: 10.1081/ESE-120005992.

[23] Aboulhassan MA, Souabi S, Yaacoubi A, Baudu M. Improvement of paint effluents coagulation using natural and synthetic coagulant aids. J Hazard Mater. 2006;138(1):40-45. DOI: 10.1016/j.jhazmat.2006.05.040. 
[24] Kabdasli I, Tünay O, Konuk K, Ețcǐoglu G, Koçabas E. Treatability of wastewaters originating from water-based paint production with latex binder. Fresenius Environ Bull. 2012;21(10A):3122-3126.

[25] Eremktar G, Goksen S, Babuna FG, Dogruel S. Coagulation-flocculation of wastewaters from a water-based paint and allied products industry and its effect on inert COD. J Environ Sci Health Part A. 2006;41(9):1843-1852. DOI: 10.1080/10934520600779018.

[26] Balasco AA. Development of a new process for treatment of paint sludge wastes. Task Order Number 6. Final Report to United States Army Toxic and Hazardous Materials Agency; 1987. www.dtic.mil/cgi-bin/GetTRDoc?AD=ADA197657.

[27] Zagklis DP, Koutsoukos PG, Paraskeva CA. A combined coagulation/flocculation and membrane filtration process for the treatment of paint industry wastewaters. Ind Eng Chem Res. 2012;51(47):15456-15462. DOI: $10.1021 /$ ie302086j.

[28] Tünay O, Kocabaş E, Olmez-Hanci T, Kabdaşh I. Characterization and treatability of latex and PVA based paint production wastewaters. Fresenius Environ Bull. 2010;19(9):1884-1888.

[29] http://www.kemipol.com.pl/products.

[30] Talinli I, Anderson GK. Interference of hydrogen peroxide on the standard COD test. Water Res. 1992;26:107-110. DOI: 10.1016/0043-1354(92)90118-N.

[31] Kang YW, Cho MJ, Hwang KY. Correction of hydrogen peroxide interference on standard chemical oxygen demand test. Water Res. 1999;33:1247-1251. DOI: 10.1016/S0043-1354(98)00315-7.

[32] Lee E, Lee H, Kim YK, Sohn K, Lee K. Hydrogen peroxide interference in chemical oxygen demand during ozone based advanced oxidation of anaerobically digested livestock wastewater. Int $\mathbf{J}$ Environ Sci Tech. 2011;8(2):381-388.

[33] US EPA Method 1311. Toxicity characteristic leaching procedure (TCLP); 1992.

[34] Markowska-Szczupak A, Ulfig K, Morawski AW. The application of titanium dioxide for deactivation of bioparticulates: An overview. Catal Today. 2011;169(1):249-257. DOI: 10.1016/j.cattod.2010.11.055.

[35] Malakootian M, Almasi A, Hossaini $\mathrm{H}$. $\mathrm{Pb}$ and Co removal from paint industries effluent using wood ash. Int J Environ Sci Tech. 2008;5(2):217-222.

[36] http://h2o2.com/industrial/applications.aspx?pid=109\&name=Formaldehyde-Oxidation.

[37] http://www.solvaychemicals.us/static/wma/pdf/6/6/2/3/TP_CostEffect.pdf.

[38] Moussayi G, Yazdanbakhash A, Heidarizad M. The removal of formaldehyde from concentrated synthetic wastewater using $\mathrm{O}_{3} / \mathrm{MgO} / \mathrm{H}_{2} \mathrm{O}_{2}$ process integrated with the biological treatment. $\mathrm{J}$ Hazard Mater. 2009;171(1-3):907-913. DOI: 10.1016/j.jhazmat.2009.06.090.

[39] Barbusiński K. Fenton reaction - controversy concerning the chemistry. Ecol Chem Eng S. 2009;16(3):347-358 and literature cited therein.

[40] Ledakowicz S, Bilińska L, Żyłła R. Application of Fenton’s reagent in the textile wastewater treatment under industrial conditions. Ecol Chem Eng S. 2012;19(2):163-174. DOI: 10.2478/v10216-011-0013-z.

[41] Bianco B, De Michelis I, Vegliò F. Fenton treatment of complex industrial wastewater: Optimization of process conditions by surface response method. J Hazard Mater. 2011;186(2-3):1733-1738. DOI: 10.1016/j.jhazmat.2010.12.054

[42] Kurt U, Avasara Y, Gonullua MT. Treatability of water-based paint wastewater with Fenton process in different reactor types. Chemosphere. 2006;64(9):1536-1540. DOI: 10.1016/j.chemosphere.2005.11.026.

[43] Koppenol WH. The Haber-Weiss cycle - 70 years later. Redox Report. 2001;6(4):229-234. DOI: $10.1179 / 135100001101536373$.

\title{
BADANIA NAD FIZYKOCHEMICZNYM PODCZYSZCZANIEM ŚCIEKÓW Z PRODUKCJI FARB DO DREWNA
}

\footnotetext{
${ }^{1}$ Wydział Technologii i Inżynierii Chemicznej, Uniwersytet Technologiczno-Przyrodniczy w Bydgoszczy

${ }^{2}$ Wydział Inżynierii Środowiska, Uniwersytet Techniczny im. Gedymina w Wilnie, Litwa

${ }^{3}$ Zakład Badań i Wdrożeń, Projprzem-Eko Sp. z o.o., Zamość k. Bydgoszczy
}

\begin{abstract}
Abstrakt: Przedstawiono wyniki badań prowadzonych na instalacji zbudowanej na potrzeby fizykochemicznego podczyszczania ścieków technologicznych w ilości do $5,0 \mathrm{~m}^{3} /$ dobę z produkcji materiałów powłokowych, ochronnych i dekoracyjnych, stosowanych na powierzchnie drewniane. Przedmiotowa, mobilna instalacja zbudowana na przenośnej palecie, składała się ze zbiornika magazynująco-uśredniającego, w którym
\end{abstract}


wyrównywanie stężeń prowadzono za pomocą napowietrzania i mieszania cyrkulacyjnego. Wariantowo w tym zbiorniku prowadzono wstępne utlenianie za pomocą nadtlenku wodoru. Zasadniczy zespół instalacji oczyszczalni tworzyły reaktory: dwa wstępne rurowe i procesowy cylindryczno-stożkowy, stacje przygotowania i dozowania reagentów oraz stacja odwadniania osadów. Stosując preutlenianie oraz podwójną koagulację kwaśno-alkaliczną układem ALCAT 105 - SAX 25, na instalacji uzyskiwano ponad 98\% redukcję zawiesin ogółem (ZO) i ekstraktu eterowego (EE), 46-54\% chemicznego zapotrzebowania na tlen (ChZT), $39-46 \%$ biochemicznego zapotrzebowania na tlen $\left(\mathrm{BZT}_{5}\right)$ i $14-27 \%$ wolnego formaldehydu (HCHO). Zastosowanie wstępnego preutleniania za pomocą nadtlenku wodoru w dawkach 250,0-450,0 mg/dm ${ }^{3}$, a następnie dwustopniowej koagulacji skutkowało wzrostem redukcji ChZT i $\mathrm{BZT}_{5} \mathrm{ca} 10-15 \%$, a $\mathrm{HCHO}$ ca 58-66\%, w relacji do wariantu bez preutleniania. Oceny powstających osadów po procesie podczyszczania dokonano, oznaczając wymywalne formy metali $(\mathrm{Cu}, \mathrm{Ni}$ and $\mathrm{Ti})$ według metodyki TCLP zgodnie z procedurą US EPA Method 1311.

Słowa kluczowe: ścieki z produkcji materiałów powłokowych do drewna, preutlenianie, fizykochemiczne podczyszczanie ścieków 